\title{
Use of Different Types of Contraceptives -Drospirenone/Ethinyl Estradiol- in Prevention of Unintended Pregnancy
}

\author{
NICOLETA NICOLAE ${ }^{1}$, CORNELUTA FIRA MLADINESCUㄹ, DANIELA VERONICA CHIRIAC ${ }^{2 *}$, LAVINIA MARIA HOGEA3*, \\ IOANA TUTA SAS ${ }^{1}$, RADU BAGIU ${ }^{1}$, IULIA BAGIU ${ }^{4}$, SALOMEIA PUTNOKY ${ }^{1}$, LACRIMIOARA PERJU DUMBRAVA ${ }^{5}$, \\ LAURA ALEXANDRA NUSSBAUM ${ }^{3}$, MIHAELA BOANCA6*, BRIGITHA VLAICU ${ }^{1}$ \\ IVictor Babes University of Medicine and Pharmacy, Department of Microbiology, 2 Eftimie Murgu Sq, Timisoara, 300041, \\ Romania \\ ${ }^{2}$ Victor Babes University of Medicine and Pharmacy, Department of Obstetrics-Gynecology, 2 Eftimie Murgu Sq, Timisoara, \\ 300041, Romania \\ ${ }^{3}$ Victor Babes University of Medicine and Pharmacy, Department of Neurosciences, 2 Eftimie Murgu Sq, 300041, Timisoara, \\ Romania \\ ${ }^{4}$ Victor Babes University of Medicine and Pharmacy, Department of Internal Medicine, 2 Eftimie Murgu Sq, 300041, Timisoara, \\ Romania \\ 5Iuliu Hateganu University of Medicine and Pharmacy, Department of Neurosciences, 8 Victor Babes Sq, 400012, Cluj Napoca, \\ Romania \\ ${ }^{6}$ Grigore T. Popa University of Medicine and Pharmacy, Faculty of Medicine, Department of Preventive Medicine, 16 Universitatii \\ Str., 700115 lasi, Romania
}

Contraception can reduce the risk of unintended pregnancies, but also allow preservation of fertility and optimizing health before pregnancy. In addition, hormonal contraceptives (drospirenone/ethinyl estradiol) reduce the risk of heavy menstrual bleeding, dysmenorrhea and some types of cancer. The research aimed to evaluate predictors of unintended pregnancy reporting at medical students of University of Timisoara in 2014-2015. The study population included 1,298 women of 18-25 years-old, 58.8\% of them being first year medicine students, and $41.2 \%$ last year medicine students. The mean age of first year female medicine students was significantly lower than the age of the last year female medicine students, $<0.001$. The working method was the transverse population survey. Unintended pregnancies were reported as $4.2 \%$ for one pregnancy and $0.5 \%$ for two or more pregnancies, with no significant difference between juniors and teens. In the multivariate model, major predictors (odds ratio, $O R>3$ ) for unwanted pregnancies were: active sexual life (in the last 3 months, $O R=4.175$ ), followed by contraceptive methods such as coitus interruptus $(O R=3.355)$, calendar method $(O R=3.235)$ and spermicidal substances $(O R=3.126)$.

\section{Keywords: hormonal contraceptives, drospirenone/ethinyl estradiol, unintended pregnancy}

Some young people are exposed to risky practices about sexual behavior, especially unwanted pregnancies and sexually transmitted diseases [1-7]. Despite the priority given to sexuality issues in schools and health care centers over the past decades, the percentage of those who do not use contraception is high [8-10]. Health promotion is addressed to the general population, and especially to those groups of young people who do not use contraception [11-14]. An article published in 2009 highlighted the fact that females aged 20-24 have one of the highest rates of unwanted pregnancies due to the inadequacy of using contraceptive methods and unsafe sexual practices [1418].

The research aimed to evaluate predictors of unwanted pregnancy reporting at 18-25-year-old medical students in Timisoara, Romania.

\section{Experimental part}

\section{Material and methods}

The sample of 1298 female medical students in Timisoara, taken in the course of 2014-2015, brings together the junior students of the first year of study and the sixthyear students.

Students in the first year are 58.8\%, $18-25$ years of age, with the highest representation of 20-year-old students. The average age of first year medicine students is 20.36 years with DS (standard deviation) 1.174 years and ESM (mean standard error) of 0.043 years. Senior medical students in the 6th year are $41.2 \%$, aged $19-25$ years old with the highest representation of 22-year-old students. The average age of the last year students is 22.09 years with the DS 1,192 years and ESM 0.52 years. The mean age of first year female students is significantly lower than the last year students, $t(1296)=-25.8, p<0.001$.

The working method was the transversal population study based on the use of the Health Risks Questionnaire for Teenagers and Young People [19]. The questionnaire was validated by the Ethics Commission of the Victor Babe 0 University of Medicine and Pharmacy Timi-oara. The study was conducted with the written approval of the university. The inclusion of young people in the study was carried out only on the basis of the free consent expressed by each participant, respecting individual rights, using some published models [20-22].

The data were processed using the PASW 18 (SPSS18) 2010 program. The statistical significance threshold was set at $p<0.05$, except where the Bonferroni correction was applied. For the ordinal data comparisons, we used the Mann-Whitney and Kruskal-Wallis test. The Chi-square test was used in ordinal/nominal data tables. The logarithmic regression test was also used to predict different patterns of association between risk behaviors. 


\section{Results and discussions}

\section{Prevalence of unwanted pregnancies}

Most of the participating women in this study had no undesirable pregnancies: $67.5 \%$ of the first year students and $76.1 \%$ of the last year students. Among the first year female medicine students, $4.1 \%$ had one undesired pregnancy, and $0.3 \%$ had two or more undesirable pregnancies. $4.4 \%$ of the last year female medicine students had an unwanted pregnancy, and $0.9 \%$ declared two or more (table 1). These data seemed to be similar to the proportion of unwanted pregnancies in young women who started their sexual life.

Reported unwanted pregnancies for young people demonstrated that sexual and reproductive activity is associated with health risks. The sexual act itself, the conception, the viable pregnancy, the fetal growth, the birth, and the postpartum period present health risks or undesirable effects, such as sexually transmitted diseases, unwanted pregnancy, fetal death, and maternal or newborn deaths. Progress through these events can be measured by the level of health and survival of mothers and children. The probability of conception during any sexual intercourse is estimated between $3 \%$ and $5 \%[23,24]$.

A UK study [25] described the prevalence of unwanted pregnancies and associated factors. One out of six pregnancies, that appeared in the year preceding the interview, was unplanned, between a quarter and a third of the respondents were ambivalent in their desire to become pregnant, and more than half of the pregnancies were planned. There have been strong associations between unwanted pregnancy and other health-related factors (smoking, drug use, depression), low educational achievements and some aspects of sexual behavior (early sexual activity, lack of sexual competence at first sexual intercourse, receiving sex education from sources other than school, increased frequency of recent sexual activity, reporting more than one heterosexual partner over the past year). Estimates from other high income countries per capita are even higher. In France, one third of pregnancies are estimated to be unplanned [26], two out of five in Spain [27], almost half in J apan [28], and one third and a half in the United States of America [29].

The univariate analysis of the contribution of factors of sexual behavior, such as the number of sexual partners and the use of contraceptives, has shown the contribution to predicting the existence of unwanted pregnancies: the existence of sexual partners in the last 3 months $(O R=$ $11.373)$, the use of spermicidal substances $(O R=6.943)$, coitus interrupt ( $O R=6.517)$, calendar method $(\mathrm{OR}=$ $5.263)$, injectable contraceptives $(O R=4.040)$.

We applied the multivariate logistic regression to assess the overall impact of some sexual behavior variables. The model contained 10 independent variables: the group (first year students vs last year students), the number of sexual partners, the existence of sex partners in the last 3 months, the age of onset of sexual life, the use of contraceptives such as condom, contraceptive pill, coitus interruptus, spermicidal substances. The complete model containing all the predictors was statistically significant, $\chi^{2}(10, \mathrm{~N}=$ $1267=96.85, p<0.001$, indicating that the model can distinguish between the respondents who declared the existence of an unwanted pregnancy and those who did notindicate this thing. The whole model explained between $7.4 \%$ and $23.0 \%$ of the variance of unwanted pregnancy reporting and correctly classified $95.2 \%$ of the cases. The risk of reporting an undesirable pregnancy $(O R=4.175)$ was 4.175 times higher for students who reported relationships in the past 3 months, and 1.4 times higher for each sex partner, controlling the effects of other factors. Early onset of sexual life $(O R=1.414)$ increased 1.414 times the probability of reporting unwanted pregnancy each year. Increased probabilities of undesirable pregnancies associated with various contraceptive methods have been increased: coitus interruptus $(\mathrm{OR}=$ $3.355)$, calendar method $(O R=3.235)$ and spermicide $(\mathrm{OR}=3.126)$ (table 2).

\section{The number of sexual partners in the last three months}

More than half of first year students (54.6\%) had one sex partner, $6.2 \%$ reported the existence of two or more sexual partners in the last 3 months. Among the category of last year students, $64.9 \%$ had one sex partner and $4.9 \%$ had sex with two or more persons (table 3 ).

The first year medicine students reported significantly higher sex partners over the past 3 months, compared to the last year medicine students, $U=172935, z=-3.94, p$ $<0.001, r=0.11$, the difference being small.

Studies have shown that more young adults report multiple sexual partners in the last 12 months compared to those aged 30 to 40-year-old [29]. Adolescents reporting a greater number of sex partners over the past 6 months, especially those who have sex with several partners during the same time period, are at a higher risk of being diagnosed with sexually transmitted diseases [30-32].

Table 1

REPRESENTATION OF THE PREVALENCE OF UNWANTED PREGNANCIES AMONG THE FIRST AND LAST YEAR FEMALE MEDICINE STUDENTS

\begin{tabular}{|c|c|c|c|c|c|}
\hline & Unwanted pregnancies & & Gro & & Total \\
\hline & & & First year students & Last year students & \\
\hline & & Number & 212 & 98 & 310 \\
\hline & I did not start my sex life & $\%$ & $28.1 \%$ & $18.6 \%$ & $24.1 \%$ \\
\hline & Norer & Number & 509 & 402 & 911 \\
\hline Unwanted & Never & $\%$ & $67.5 \%$ & $76.1 \%$ & $71.1 \%$ \\
\hline pregnancies & & Number & 31 & 23 & 54 \\
\hline & 1 pregnancy & $\%$ & $4.1 \%$ & $4.4 \%$ & $4.2 \%$ \\
\hline & Oormore nrarnancio & Number & 2 & 5 & 7 \\
\hline & 2 or more pregnancies & $\%$ & $0.3 \%$ & $0.9 \%$ & $0.5 \%$ \\
\hline & Total & Number & 754 & 528 & 1282 \\
\hline & 10 olal & $\%$ & $100.0 \%$ & $100.0 \%$ & $100.0 \%$ \\
\hline
\end{tabular}


Table 2

THE UNIVARIATE AND MULTIVARIATE LOGISTIC REGRESSION INDICATORS FOR THE PRELIMINARY MODEL OF REPORTING UNWANTED PREGNANCIES

\begin{tabular}{|c|c|c|c|c|}
\hline Indicator & Univariate OR & C.I. 95\% from OR & Model OR & C.I. 95\% from OR \\
\hline First year vs last year students & 0.817 & $0.488-1.370$ & 1.032 & $0.588-1.809$ \\
\hline The number of sexual partners & 1.713 & $1.469-1.997$ & 1.401 & $1.162-1.689$ \\
\hline The age of onset of sexual life & 1.775 & $1.443-2.182$ & 1.414 & $1.055-1.897$ \\
\hline The existence of sex partners in the last & 11.373 & $3.543-36.507$ & 4.175 & $1.239-14.064$ \\
3 months & & & & \\
\hline Condom & 1.347 & $0.804-2.256$ & 0.989 & $0.556-1.758$ \\
\hline Contraceptive pill & 2.490 & $1.484-4.179$ & 1.642 & $0.917-2.937$ \\
\hline Calendar method & 5.263 & $2.803-9.884$ & 3.235 & $1.557-6.721$ \\
\hline Injectable contraceptives & 4.040 & $0.465-35.123$ & 0.732 & $0.047-11.440$ \\
\hline Coitus intemuptus & 6.517 & $3.620-11.731$ & 3.355 & $1.700-6.622$ \\
\hline Spermicidal substances & 6.943 & $1.831-26.327$ & 3.126 & $0.643-15.202$ \\
\hline
\end{tabular}

Legend: $\mathrm{OR}=$ odds ratio; $\mathrm{CI}=$ Confidence Interval

Table 3

DISTRIBUTION OF FIRST YEAR AND LAST YEAR STUDENTS BY THE NUMBER OF SEXUAL PARTNERS IN THE LAST 3 MONTHS

\begin{tabular}{|c|c|c|c|c|c|}
\hline \multicolumn{3}{|c|}{ The number of sexual partners in the last three months } & \multicolumn{2}{|c|}{ Group } & \multirow[t]{2}{*}{ Total } \\
\hline & & & $\begin{array}{l}\text { First year } \\
\text { students }\end{array}$ & $\begin{array}{l}\text { Last year } \\
\text { students }\end{array}$ & \\
\hline \multirow{8}{*}{ Sexual partners } & \multirow{2}{*}{ I had no sexual partner } & Number & 208 & 97 & 305 \\
\hline & & $\%$ & $27.5 \%$ & $18.3 \%$ & $23.7 \%$ \\
\hline & \multirow{2}{*}{$\begin{array}{l}\text { I had no sexual partner in the last } \\
3 \text { months }\end{array}$} & Number & 88 & 63 & 151 \\
\hline & & $\%$ & $11.7 \%$ & $11.9 \%$ & $11.8 \%$ \\
\hline & \multirow{2}{*}{1 sexual partner } & Number & 412 & 344 & 756 \\
\hline & & $\%$ & $54.6 \%$ & $64.9 \%$ & $58.8 \%$ \\
\hline & \multirow{2}{*}{2 or more sexual partners } & Number & 47 & 26 & 73 \\
\hline & & $\%$ & $6.2 \%$ & $4.9 \%$ & $5.7 \%$ \\
\hline \multirow{2}{*}{\multicolumn{2}{|c|}{ Total }} & Number & 755 & 530 & 1285 \\
\hline & & $\%$ & $100.0 \%$ & $100.0 \%$ & $100.0 \%$ \\
\hline
\end{tabular}

An analysis of the Agency for Research on Cancer, USA confirmed that the number of sex partners was an important risk factor for HPV infection [33]. Other studies have shown that the number of sexual partners is an independent risk factor for cervical cancer [34].

A meta-analysis published in 2015 suggests that the number of sexual partners is associated with the development of cervical cancer [35]. The association remains significant after the control for HPV infection. This indicates that women with multiple sexual partners are exposed to a higher risk for developing cervical cancer, even if HPV vaccination is being applied.

\section{Types of contraceptive methods used}

When it comes to the choice of type of contraceptive method, $46.24 \%$ of first-year students choose condom, $29.72 \%$ contraceptive pill, $6.47 \%$ calendar method, and the rest of contraceptive methods are less frequently chosen by young women from this group.

$47.92 \%$ of last year's students choose condom, $37.92 \%$ contraceptive pill, $6.98 \%$ calendar method. Similar to first year students, the first two methods are much more popular than all other (table 4).

-CONDOM is used as a physical barrier to prevent pregnancy and spread of sexually transmited diseases.
- Male condoms are commonly made from latex, polyurethane or other synthetic materials such as AT-10 resin and polyisoprene.

- Female condoms are made from polyurethane or nitrile rubber.

Some people experience allergic reaction to condoms: 1 spermicide condom allergy because of NANOXYNOL9 (an ingredient of all spermicide);

2 latex condom allergy (some individuals develop allergic reactions to certain proteins in rubber latex,wich can manifest in mild,to moderate symptoms).

The molecular formula of polyurethane is C27H36N2O10 and it's molecular weight is $548.589 \mathrm{~g} / \mathrm{mol}$.

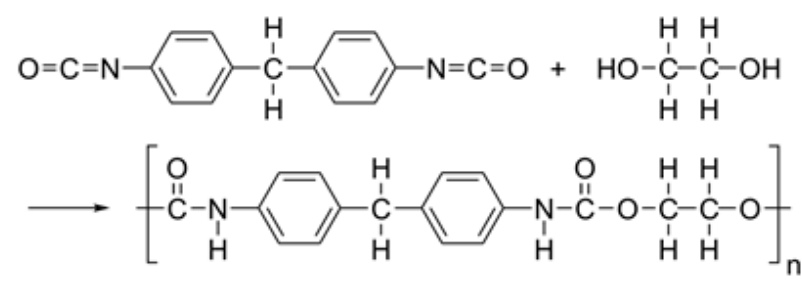

Fig. 1.

Polyurethane synthesis, where in the urethane groups $\mathrm{NH}-(\mathrm{C}=0-0$-link the molecular units. 


\begin{tabular}{|c|c|c|c|}
\hline \multirow{2}{*}{ Contraceptive methods } & \multicolumn{2}{|c|}{ Group \% } & \multirow{2}{*}{ P } \\
\cline { 2 - 3 } & First year & \multirow{2}{*}{$\begin{array}{c}\text { Last year } \\
\text { students }\end{array}$} & \\
\hline No contraceptive methods & 5.42 & 4.34 & 0.382 \\
\hline Condom & 46.24 & 47.92 & 0.550 \\
\hline Contraceptive pill & 29.72 & 37.92 & 0.002 \\
\hline Calendar method & 6.47 & 6.98 & 0.719 \\
\hline Injectable contraceptive & 0.26 & 0.75 & 0.204 \\
\hline Coitus interruptus & 5.94 & 10.19 & 0.005 \\
\hline Diaphragm & 0.13 & 0.57 & 0.169 \\
\hline IUD (intrauterine device) & 0.00 & 0.19 & 0.232 \\
\hline Spermicidal substances & 0.92 & 0.94 & 0.973 \\
\hline
\end{tabular}

Table 4

PREVALENCE OF THE CONTRACEPTIVE METHODS USED BY FIRST YEAR AND LAST YEAR STUDENTS
-SPERMICIDAL SUBSTANCES -NONOXYNOL-9

Nonoxynol-9 (N-9) is a typical surfactant used as a vaginal sperm. The chemical formula of nonoxynol - 9 is C33H60010 (fig. 2):<smiles>CC(C)(C)CCOc1ccc(C(C)(C)C)cc1</smiles>

Fig. 2.

\section{-CONTRACEPTIVE PILLS -DROSPIRENONE/ETHINYL}

\section{ESTRADIOL}

The contraceptive pill contains (drospirenone/ethinyl estradiol):

-Drospirenone is a synthetic progestational compound and has a molecular weight of 366.5 and a molecular formula of $\mathrm{C} 24 \mathrm{H} 3003$.

-Ethinyl estradiol (19-nor-17 $\alpha$-pregna 1,3,5(10)-triene20-yne-3,17-diol) is a synthetic estrogenic compound and has a molecular weight of 296.4 and a molecular formula of $\mathrm{C} 2 \mathrm{OH} 2402$.

The structural formulas are as follows (fig. 3.)

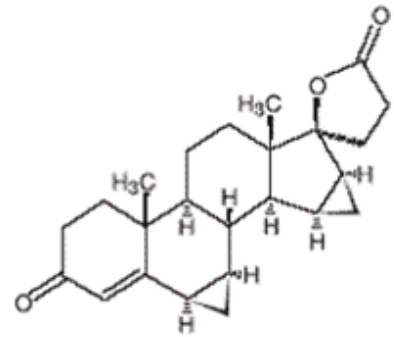

Drospirenone

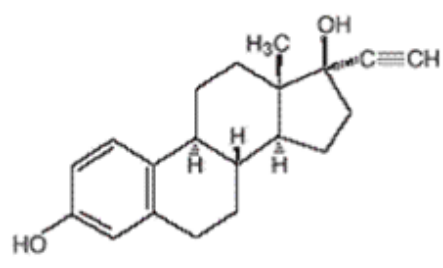

Ethinyl estradiol
Fig. 3.

-With the exception of the contraceptive pill $\left(\chi^{2}=9.5, p\right.$ $=0.002, \mathrm{OR}=1.445,95 \% \mathrm{IC}=1.142-1.827)$ and intermittent coitus $\left(\chi^{2}=7.9, p=0.005, \mathrm{OR}=1.795,95 \%\right.$ $I C=1.189-2.711$ ), with a higher prevalence of use among the last year students than the first year students, for the rest of the contraceptive methods the prevalence of use is similar between groups.

In the YRBSS 2015 study the results showed high percentages of young people using condom as a contraceptive method, $56.9 \%$ reporting the use of a condom during the last sexual intercourse. Prevalence of condom use was higher for male students, $61.5 \%$ than for females, $52.0 \%$ [31].

Contraception is a way to prevent pregnancy. We also try to reduce the risk of sexually transmitted diseases [3739]. Although contraceptive methods are largely adequate for female sex, contraception for men should also be addressed [40,41]. The only contraceptive that offers a significant reduction in the risk of pregnancy and STD (sexual transmitted disease) is the condom [42-44]. Condom use, the most commonly used method, helps to avoid pregnancy by blocking the passage of sperm into the vaginal cavity. Protection against STD is limited, but it is the only method that protects both partners. Even if used correctly and consistently, the condom does not offer $100 \%$ protection against pregnancy and STD (85-98\% effectiveness) [45]. Using the contraceptive pill attempts to inhibit the natural secretion of female sex hormones to prevent ovulation, and fertilization cannot take place. For oral contraceptives used correctly, the risk of pregnancy is quite low (96-99\% effectiveness). This method of contraception does not offer protection against STDs. The following places, as frequency of use, are behavioral methods, calendar method and coitus interruptus. The risk of pregnancy is increased (efficiency 65-80\%) and protection against STD is not ensured [46, 47]. In 20082014, the three most common methods among contraceptive users (the contraceptive pill, female sterilization and condom, and the intrauterine device) replaced male sterilization as the fourth most common method [48-50].

\section{Conclusions}

In order to prevent unintended pregnancy, methods should be considered in contraceptive counseling. The counseling should focus on effective contraception, like contraceptive pill and avoidance of the consequences of unintended pregnancy.

In our experimental study we reported a percentage of unintended pregnancies of $4.2 \%$ for one pregnancy and of $0.5 \%$ for 2 or more pregnancies in the age group of 18-25 years old, with no significant differences between the first year and the lastyear medicine students. In the multivariate model, the major predictors $(O R>3)$ for unwanted pregnancies were active sexual life (over the last 3 months), followed by contraceptive methods such as intermittent coitus, timing method, and spermicidal substances.

\section{References}

1.FIRA-MLADINESCU, C., In: Vlaicu B (Ed.), Editura Solness Timiooara, 2000, p. 226.

2.REDDY, S.P., MEYER-WEITZ, A., Tygerberg, Medical Research Council, 1999.

3.HOGEA, L.M., NUSSBAUM, L.A., CHIRIAC, D.V., AGEU, L.S., ANDREESCU, N.I., GRIGORAS, M.L., FOLESCU, R., BREDICEAN, A.C., PUIU, M., ROSCA, E.C.I., SIMU, M.A., LEVAI, C.M., Rom. J. Morphol. Embryol., 58, No.3, 2017, p. 767. 
4.NUSSBAUM, L.A., HOGEA, L.M., CHIRIAC, D.V., GRIGORAS, M.L., FOLESCU, R., BREDICEAN, A.C., ROSCA, E.C.I., MUNCAN, B., NUSSBAUM, L.M., SIMU, M.A., LEVAI, C.M, Rom. J. Morphol. Embryol., 58, No.4, 2017, p. 1435.

5.HOGEA, L.M., SAS, I.T., POROCH, V., NUSSBAUM, L.A., SAS, I., SERBAN, D., ERDELEAN, D., FOLESCU, R., ZAMFIR, C.L., BREDICEAN, A.C., SIMU, M.A., Rev. Chim. (Bucharest), 69, no. 4, 2018, p. 934.

6.BAGIU, I.C., VLAICU, B., ONISEI, D., ONISEI, D., BAGIU, R.V., Rev. Chim. (Bucharest), 67, No 9, 2016, p.1684.

7.NUSSBAUM, L.A., HOGEA, L.M., FOLESCU, R., GRIGORAS, M.L., ZAMFIR, C.L., BOANCA, M., ERDELEAN, D., ROSCA, E.C.I., NUSSBAUM, L., SIMU, M.A., LUPU, V., Rev. Chim. (Bucharest), 69, no 4, 2018, p. 965.

8.AGEU, L.S., LEVAI, C.M., ANDREESCU, N.I, GRIGORAS, M.L., HOGEA, L.M., CHIRIAC, D.V., FOLESCU, R., BREDICEAN, A.C., NUSSBAUM, L.M., ENATESCU, V.R., POROCH, V., LUPU, V., PUIU, M., NUSSBAUM, L.A., Rom. J. Morpho.I Embryol., 59, No. 1, 2018, p. 165.

9.PAPAVA, I. OANCEA, C., ENATESCU, V.R., BREDICEAN, A.C., DEHELEAN, L., ROMOSAN, R.S., TIMAR, B., Int. J. Chron. Obstruct. Pulmon. Dis., 11, 2016, p. 1343.

10.KONIAK-GRIFFIN, D., LESSER, J., UMAN, G., et al, Research in Nursing \& Health, 26, No 1, 2003, p.4.

11.MITRANOVICI, M.I., PUSCASIU, L., CRAINA, M., IACOB, D., CHIRIAC, V.D., IONITA, I., MOLERIU, R.D., FURAU, G., SISU A., PETRE, I.Z., Rev. Chim. (Bucharest), 68, no. 12, 2017, p. 2970.

12.CALAMAR POPOVICI, D., IONITA, I., IONITA, C., MARINITA, A., MOLERIU, R.D., IONITA, H., IACOB, D., CHIRIAC, V.D., PETRE, I., Rev. Chim. (Bucharest), 68, no. 10, 2017, p. 2463.

13.POPA, Z., CHIRIAC, V.D., COBEC, I.M., LUNGEANU, D., CRAINA, M., BERNAD., E., IONITA, I., MOLERIU, R.D., IACOB, D., PETRE, I., Rev. Chim (Bucharest), 68, no. 10, 2017, p. 2459.

14.MOGA, M.A., IRIMIE, M., OANTA, A., PASCU, A., BURTEA, V., Asian Pacific J. of Cancer Prev., 15, No. 16, 2014, p. 6887. DOI: 10.7314/ APJCP.2014.15.16.6887.

15.*** NACO, New Delhi, Ministry of Health and Family Welfare, 2002.

16.. ENATESCU, V.R., BERNARD, E., GLUHOVSCHI, A., et al, J ournal of Health, 26, No 3, 2017, p. 212.

17.PETRESCU, C., VLAICU, B., Rev. Med. Chir, 119, No.1, 2015 p.230. 18.OLARU, F., OLARU, C., OLARU, V., NUSSBAUM, L., HOGEA, L., FOLESCU, R., GRIGORAS, M., PASCU, A.M., POROCH, V., ERDELEAN, D., Rev. Chim. (Bucharest), 70, no. 1, 2019, p. 211.

19.BRYANT, K.D., ABNF J., 20, No. 1, 2009, p. 12.

20.POROCH, V., AGHEORGHIESEI, D.T., Postmodern Openings, 9, no. 2, 2018, p. 225.

21.AGHEORGHIESEI CORODEANU, D.T., POROCH, V., 6th LUMEN International Conference on Rethinking Social Action Core Values,1619 April 2015, Iasi, Romania, Rethinking Social Action. Core Values, p. 33.

22.ROGOZEA, L., REPANOVICI, A., CRISTEA, L., BARITZ, M., MICLAUS, R., PASCU, A., Proceedings of the 4th WSEAS/IASME International Conference on Educational Technologies (Edute'08), Book Series: Recent Advances in Computer Engineering, Corfu, Greece, 2008, Oct. 26-28, p. 87.

23.URSONIU, S., PUTNOKY, S., VLAICU, B., Wiener Klinische Wochenschrift, 123, No. 11-12, 2010, p. 327.

24.TIETZE, C., Fertil Steril., 11, 1960, p. 485.
25.WELLINGS, K., J ONES, K.G., MERCER, C.H., Lancet, 382, No. 9907, 2013, p. 1807.

26.BAJ OS, N., LERIDON, H., GOULARD, H., Hum. Reprod., 18, 2003, p. 994.

27.FONT-RIBERA, L., PEREZ, G., SALVADOR, J., J. Urban Health, 85, 2008, p. 125.

28.GOTO, A., YASUMURA, S., REICH, M.R., FUKAO, A., Soc. Sci. Med., 54, 2002, p. 1065.

29.MOSHER, W.D., JONES, J., ABMA, J.C., National Health Statistics Report, 2012. 55, No. 24, 2012.

30.J OHNSTON, L.D., O'MALLEY, P.M., BACHMAN, J.G., HIV/AIDS: Institute for Social Research, University of Michigan, 2014.

31.ASHENHURST, J.R., WILHITE, E.R., HARDEN, K.P., Archives of Sexual Behavior, 45, No. 3, 2016.

32.ROSCA, E.C., ROSCA, O., SIMU, M., Neurologist, 18, No.2, 2012, p. 64.

33.VACCARELlA, S., FRANCESCHI, S., HERRERO, R., Cancer Epidemiol. Biomarkers Prev., 15, 2006.

34.WANG, P.D., LIN, R.S., Gynecol. Oncol., 62, 1996, p. 10.

35.LIU, Z.C., LIU, W.D., LIU, Y.H., Asian Pacific Journal of Cancer Prevention, 16, 2015, p. 3893.

36.*** Centers for Disease Control and Prevention. Surveillance Summaries, 65, No. 6, 2016.

37.*** Departement of Health and Human Services, Center for Disease Control and Prevention, USA, 2005.

38.GADALEAN, F., SIMU, M., PARV, F., Plos One, 12, No. 10, 2017, p. 1. 39.SHIFERAW, Y., ALEMU, A., ASSEFA, A., BMC Research Notes, 7, 2014, p. 162.

40.CHIRIAC, V.D., HOGEA, L.M., BREDICEAN, A.C., Rom. J. Morphol. Embryol., 58, No. 3, 2017, p. 1023.

41.KIM, K.J., CONGER, R., LORENZ, F., ELDER, J.R., Developmental Psychology, 37, 6, 2001, p. 775.

42.HOGEA, G.B., ANDOR, B.C., TOTOREAN, A., HOGEA, L.M., NUSSBAUM, L.A., BISTRIAN, A., SANDESC, M.A., FOLESCU, R., STANCIULESCU, M.C., DOBRIN, P.R.., BOANCA, M., PATRASCU J r., J.M., Rev. Chim. (Bucharest), 69, no. 12, 2018, p. 3530.

43.HOGEA, G.B., PATRASCU J r., J.M., SANDESC, M.A., BREDICEAN, A.C., NUSSBAUM, L.A., HOGEA, L.M., LAITIN, S.M.D., ERDELEAN, D., CHIRIAC, D.V., MUNTEAN, F.L., CHIRIAC, S.D., Rom. J. Morphol. Embryol., 59, No. 3, 2018, p. 741.

44.CAVAZOS-REHG, P.A., KRAUSS, M.J., SPITZNAGEL, E.L., 82, No. 6, 2010, p. 549.

45.REMSCHMIDT, C., FESENFELD, M., KAUFMANN, A.M., DELERE, Y., BMC Public Health, 14, 2014, p. 1248.

46.HIGGINS, J.A., POPKIN, R.A., SANTELLI, J.S., Perspect. Sex Reprod. Health, 44, No. 4, 2012, p. 236.

47.ROCCA, C.H., HARPER, C.C., RAINE-BENNETT, T.R., Perspect. Sex Reprod. Health, 45, No. 1, 2013, p. 23.

48.CIOBOTEA, D., VLAICU, B., CIUBARA, A., Revista de Cercetare si Interventie Sociala, 54, 2016, p. 66.

49.KAVANAUGH, M.L., JERMAN, J., Contraception, 97, 2018, p. 14.

50.STELEA, L., PETRE, I.; CRAINA, M., VLADICU, B., SISU, A., POP, E., MOLERIU, R.D., IVAN, M.V., NOVAK, T., FULGER, L., Rev. Chim. (Bucharest), 69, no. 7, 2018, p. 1842

$\overline{\text { Manuscript received:11.01.2019 }}$ 